\title{
介紹華北農業科學研究所
}

\section{一 史略和概况}

萧北旺業科學研究所的前身可以分瓷兩個時 期, 就是日冦侵佔時期和國民黨統治時期。日冦在

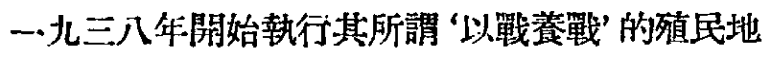

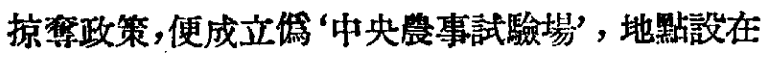
北京西郊，一九四○年改稱傜 “華北曹事試驗場'， 以期更深入地撗大對華北農業資源的掠集。

一九四五年秋，日完投降，國民黨反動政府

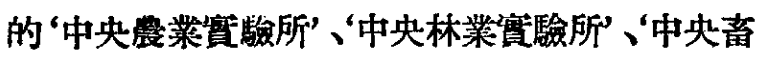
牧賴驗所” 和 “華北獸器防治處” 分別 接牧了它的 農業、林業、畜牧、㽬醫部分。這一封建性的分㓢， 使整储試䐘研究工作蒙受了莫大的損失。此外, 由 於反動政府的牛殖民地牛封建性的敗細菌早已

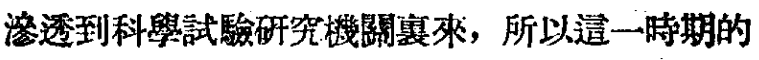
工作, 就更談不到付桹成就。

北平解放後, 前華北人民政拊第了使農業科 學研究工作走向正規化的道路, 和配合翌察們急: 切的要求, 於一九四儿年四月二十日, 將上述四個

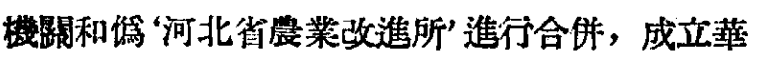
北農業科學研究所。

解放時, 上述五個機關的報到人数計行政人 員129人，技街人員 208 人，工人 464 人。後㮒兩次整

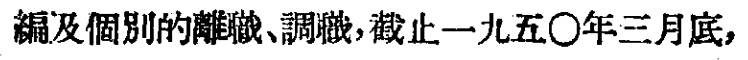
全所䟽工納數傜 617 人，其中行政人員 80 人，技街 人員 171 人，練㕷生 4 人，技街工人 23 人,農工 190 人,一般工人73人,夫役76人。

技術部門，現梪入個系，二十二個研究空，兩 调委員會，一個氣象觀測站，構成了全所的研究能 系。其組織系統如下:

(一)農作物系: 麥作研究室, 襍糧研究室, 棉 作研究室,特用作物研究室。

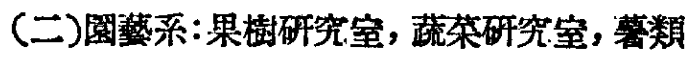
研究空。

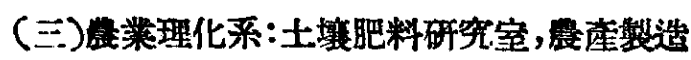
研究室, 氣像䚋测站。

(四)植物苪虫害系: 病害研究室，虫害研究 室,楽劑研究室。
（五）應用植物學系:生理生熊研究空,細胞逞 傅研究空。

(六)森林系: 造林研究空, 炼林利用研究室。 森林經理研究室。

(七)家畜防疫系:病毒研究室,細菌研究室。

（八）畜牧柔:飼苓管理研究室,調查研究宣。

(九)推廣委員會。

（十）編輯委員會圖書資料空。

\section{二患業科䁷研究的数方向}

根據中央農紫部全國農業生產會議指示, 一 九五○年的工作計㓶, 以粞棉堺産的試驗研究偍 主姴任務。其他一切試驗研究工作均㻴繞此目標 而進行。此外,亚開始進行了全所規模的米邱林學 說的研究。

在以糧棉㒄產篇主的要求下, 目前特别着重 各種䅉作物品種的改良, 病害虫害防洽法的研究， 土壤把料的改良。例如，小㮃研究着重冬小麥的豐

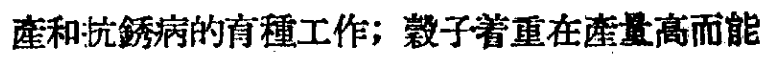
抗白肯病的育種工作; 王米則著重利用誰交程的

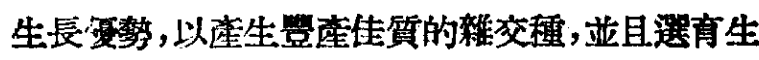
育期经的早熟品種; 棉花則着重传良品程的保种

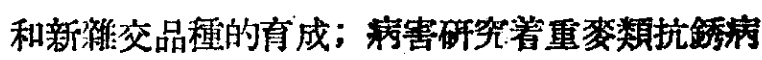
和雜煌作物抗黑穗病、白集芴的研究; 虫害究研則 着重:主要害虫蟭蛅、行軍虫、螅虫、蚜虫的防治法

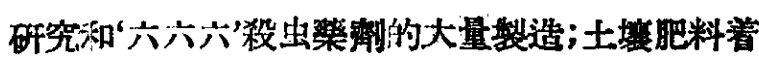
重華北區地力测定和花生根源菌接種的研究。

關於米邱林學說的最基本的理論研究和在管

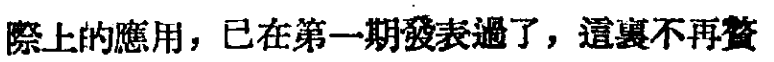
速。

\section{三 建立新制度,改造䇴作風}

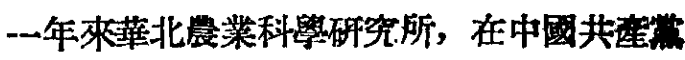
的領学與鼓舞下，完全以新的瓷態出現，它不㑤完

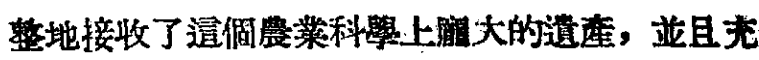

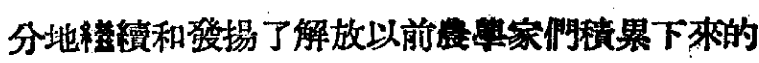
成果, 完全走向一切篇人民的道路上去。在全所六 百稌耧工共同努力之下，逐渐地掦菒了某些不適 
用的真西，凔遗了一套新的工作作法：

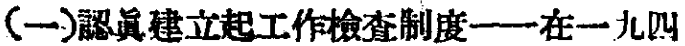

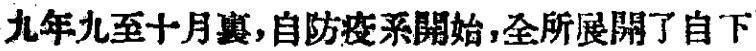
而上的工作大檢查，並作出螕結，明確地找出以往 的缺和今後稺法。曲遭次工作大检查, 已立分 鿁明柃查制度是“他們工作的推進機”，他們装認员 把它建立和健全起來, 使他們的工作, 在不斷的检 查中不断地提高。在景次檢查總䋨中，他們完成下 列最具敛而迫切的幾作工作：（1）克服系、室主

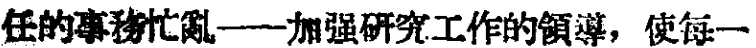

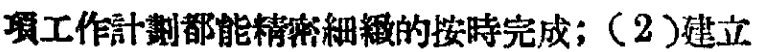

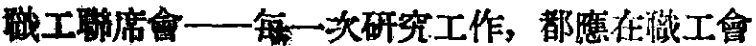
上共同鼓汁，在進行中共同检查，最後共闹總絬，

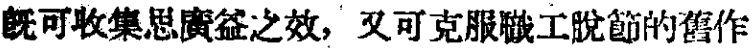

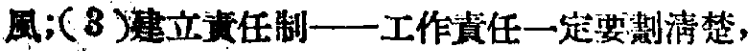
促工作责任上是分工筫貲, 在工作進行上是合作

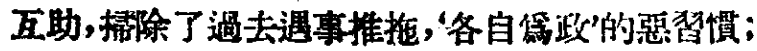
(4)箱化研究项目一一項目太多, 人少顧不来，一

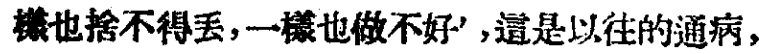

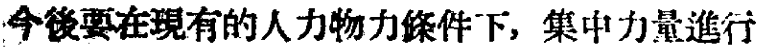

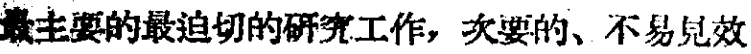

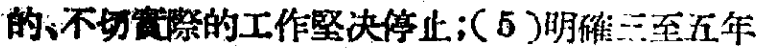

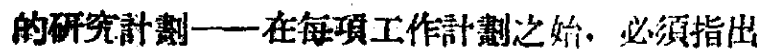

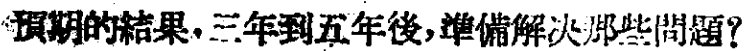

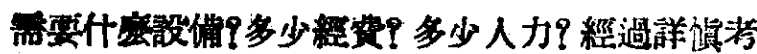

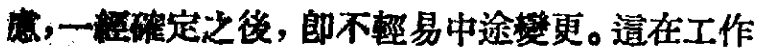
行上检查上都是必要的。

(二)調查和资驗研究的続合一一毛主帛說：

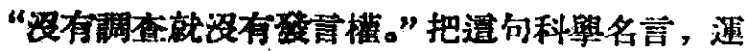
用到他們的工作部門中去，就焚成“汥有調查，就涩

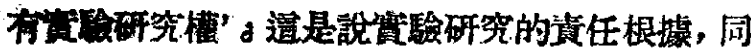

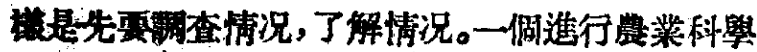
研究的工作者，如果不到磷村去裯查和探集，一次 刃一次以至無数次的研究材料，是不會解决筫際 成的的。

華北海科㖏研究所在一九四九年八至九月

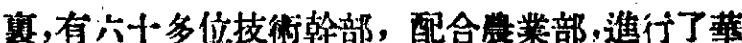

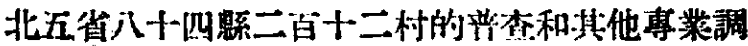

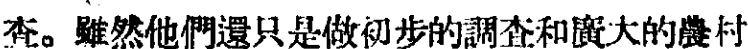

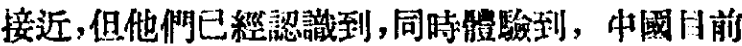

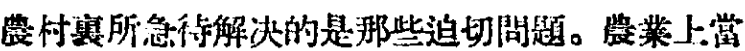
前最大的問題是各種作物的病出㲅防治, 汥伯適

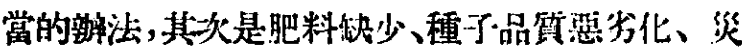

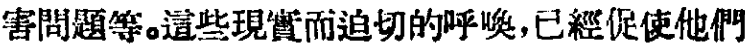

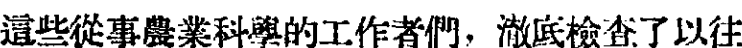
工作方法的錯誤和偏向，而普泊地一致地要求把 工作轉向一個新方向，進入一個新的階段。闹時他

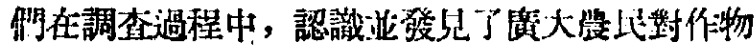

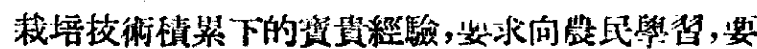
求把試驗研究的農場和陵民的由埸打成一片, 把

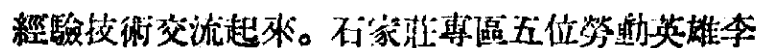

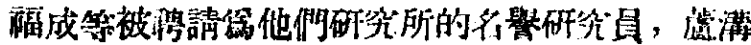

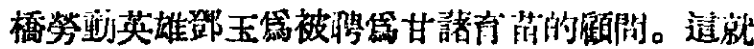

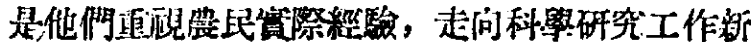
方向的具躤說明。

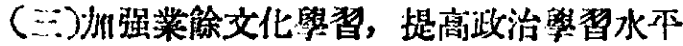

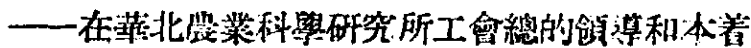

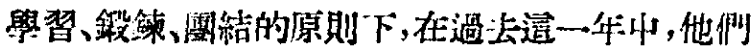

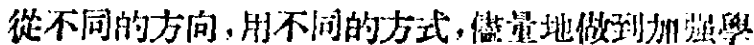

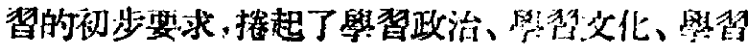

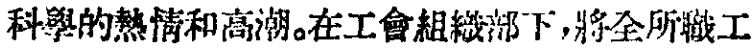
同志縟組了四十八個小組，亚定每星期三筑工會

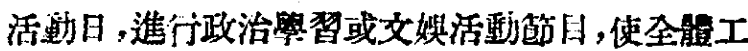
作人員在繁忙的緊張生活震，有一倜俱樂歡䛧的

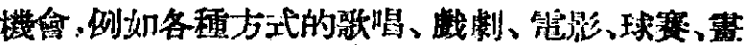
展、晚會等。在文化教育方面，目前着重在工人文

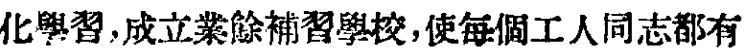
學習文化、提嵪文化的可能和機會。在幹部方面， 除去一般政治文化學習外，特别着重專題疆講舉

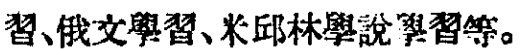

（劉泰、黄卓明）

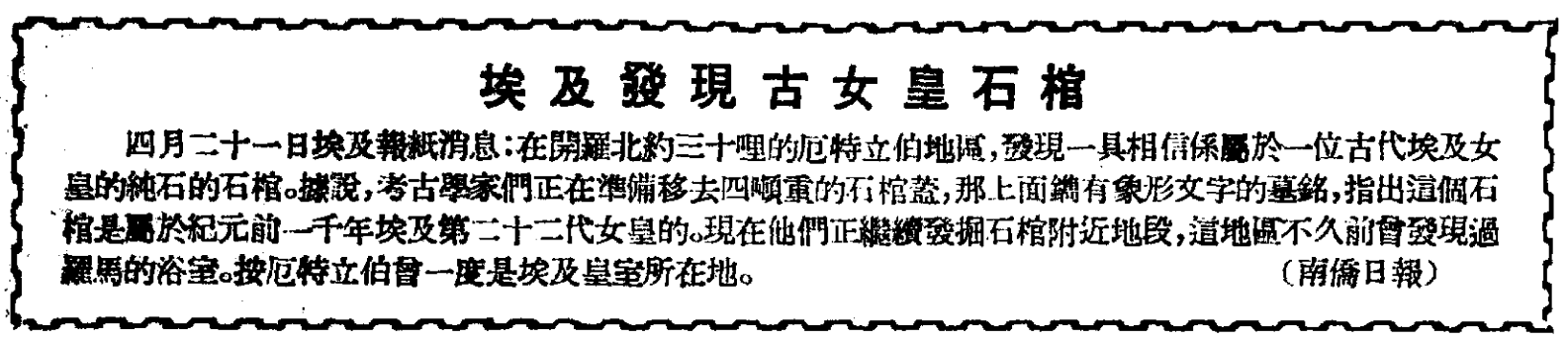

